\title{
The Influence of Education Policy Implementation Toward the Availability of Professional Teachers In 3T Areas in Indonesia
}

\author{
$1^{\text {st }}$ Risma Niswaty \\ Office Administration Education \\ Department \\ Universitas Negeri Makassar \\ Makassar, Indonesia \\ risma.niswaty@unm.ac.id
}

\begin{abstract}
Integrated professional teacher education is a national program for the procurement of elementary and secondary school teachers for 3T areas that are underdeveloped, underleading, and outer regions. PPGT Office Administration Education is one part of the program. The program is implemented since 2011 and ends in 2018, consisting of three batches. During the program, they were educated for five years. Four years for completion of undergraduate study and continued one year of professional teacher program. After three batches of PPGT program implementation, it was found that the alumni of this program had returned to their respective home areas. Nevertheless, there are many obstacles in performing their duties as teachers prepared for teaching in vocational schools. The research type is quantitative design on eksplanatory survey approach, multiple linear regression analysis with validity method of product moment pearson test and reliability test that is alpha cronbach technique for hypothesis test is path analysis and statistical test $(t)$. The datum transformation is a Likert Scale with a successful interval measurement method. Population amounted to one hundred and seven people with stratified random sampling technique samples, questionnaire instrument research using google form and alumni interview via voice note available on whatsapp media. The result of assuming research that it is anticipated that implementation of change policy implementation " $X$ ", there is significant influence to the availability of professional teachers in $3 \mathrm{~T}$ areas $(\mathrm{Y})$ is $66.31 \%$ and the other factor (e) is $33.69 \%$. In the implementation factor is significant to positif influence to quality service is Communication $\left(X_{1}\right)$ is $0,49 \%$, Human resources $\left(X_{2}\right)$ is $0,25 \%$, Disposition $\left(\mathbf{X}_{3}\right)$ is $0,32 \%$ and Structure Birocratic $\left(\mathbf{X}_{4}\right)$ is $0,33 \%$. The conclusion from four factor independen variable $(\mathrm{X})$ is the influence of policy implementation to availability of professional teachers in 3T areas $(Y)$ to influence and can receive in knowledge. To conceptualize development in policy implementation needs support from inter-institutional coordination factors, especially for national programs involving multi-ministry and local government involvement.

Keywords - Integrated professional teacher education, 3T areas, Education Policy Implementation
\end{abstract}

\section{INTRODUCTION}

One of the policies of the Ministry of Education and Culture in order to accelerate the development of education in the 3T (underdeveloped, foremost, and outermost areas), is the Indonesian Intellectual Mutual Program (MBMI) [1][3]. The program includes (1) Integrated Teacher
Professional Education Program and Additional Authority (PPGT), (2) Educational Undergraduate Program in 3T (SM-3T), and (3) Collaborative Teacher Professional Program (PPG Colaborative). These programs are part of the answer to address various education issues in 3T areas. Underdeveloped areas are areas with low development achievement, have an index of economic development progress and Human Resources below the national average index (RPJM 2010-2014). The foremost regions are districts / municipalities that are geographically and demographically adjacent to neighboring countries [4]. Outermost areas are districts / municipalities that are geographically and demographically adjacent to the open seas.

Especially for the provision of Vocational High School (SMK) teachers, there is an Integrated Teacher Professional Program and Additional Authority (PPGT). This program is designed and implemented for three batches of programs, namely batch of 2011, 2012, and 2013. Each batch must complete a two-part program: 1) a four-year degree program; and 2) Teacher Professional Education Program (PPG) which lasted for one year.

After PPGT has alumni for these three batches, then the problem that arises is when the participants of PPGT Program have completed professional education of teachers and they return to their respective areas, there is a synchrony between central policy and policy at provincial and regency/city level. The reality condition is far from the expectations of the participants of the PPGT Program. They did not necessarily get Master Number (NGR) and Unique Number of Teachers and Education Personnel (NUPTK). In order to obtain these numbers they still have to go through common procedures like other regular scholars. As for several requirements that must be met are 1) Decree of the Regent / Mayor; 2) Devotion for several Years and other requirements. This condition is of course very different from the purpose and the initial concept of the establishment of PPGT. follow.

\section{RESEARCH METHODS}

This research explained and analyzed levels of influence independen variable on variables bound dependent variable [5]. The kind of research is using the quantitative design with the approach the method explanatory survey that 
explains analyze the effect of the implementation of education policy on the availability of professional teachers in disadvantaged, leading, and outer areas (3T), Both in the partial or whole of factors influence the implementation of this policy. An analysis of the data used in this research was regresion linier multipel analysis which is followed by using analysis lane (Path Analysis), The validity of testing research instruments so that reliable) andreliable, Testing conducted first to collect data that has validity and done reliability high the approach that was undertaken with analyze beforehand to collect the data that has validity and product moment pearson correlation, Which includes steps namely ; The determination of correlation value ( $r$ ); rate determination $\mathrm{t}=$ calculate ; The withdrawal of the decision rule; And the criteria for interpretation. Next research would be conducted the approach Alpha Cronbach, To test the reliability, index will show the extent to which an instrument used to measure the same symptoms and is relatively consistent. The ordinal of the level of the measurement of data being the interval with trasformation likert scale of the answer is the answer categories covered consisting of 5 category consisting of the answer: strongly agree, agree, not agree, doesn't agree, very not agree. The answer is adapted to form the questions covered with respondents based on situation and condition factual. The determination of correlation value ( $r$ ) with the formula as follows:

$$
r=\frac{\left.N(\square x y)^{-(} \square x \square y\right)}{\left(N \square x^{2}-(\square x)^{2-N} \square y^{2}-\square y\right)^{2}}
$$

Each answer respondents are score, that they would be used for, the measurement of an ordinal the score is used for purposes related to the interval by a method of analysis "Method af Successive Intervals" (MSI) To be processed in quantitative, the ordinal of data transferred to the data in the interval Path Analysis [6]. Technik the sample collection that is used is Stratified Random Sampling, With a population of targets in this research were 107 respondens in PPGT alumni from two generations, the 2011 and 2012 periode that have completed PPG program at Universitas Negeri Makassar, State University of Malang, State University of Yogyakarta, and Jakarta State University.

\section{RESULTS AND DISCUSSION}

The effect of changes in the implementation of education policy towards the availability of professional teachers in $3 \mathrm{~T}$ areas based on the results of research and statistical test for the variables of implementation of education policy implementation implementation with symbol (X); Which includes factors in communication (X1) with indicators; Transmission, clarity, consistency, resources (X2) With indicators: staff, information, authority, facilities. Managerial attitude (X3) with indicators: behavior, incentives, and bureaucratic structure (X4) with indicator: standard operating procedure, on increasing the significance of fragmentation affects the availability of professional teachers in $3 \mathrm{~T}(\mathrm{Y})$ area with dimension that is reliability of professional teacher availability. The performance of professional educators includes: Pedagogic Competencies, Personality
Competencies, Social Competencies, and Professional Competencies.

TABLE I. RECAPITULATION OF TEST RELIABILITY RESULT

\begin{tabular}{|c|c|c|}
\hline Variable & Score & Explanation \\
\hline Implementation of Policy & 0,853 & Reliable \\
\hline Quality of service & 0,807 & Reliable \\
\hline
\end{tabular}

Table 1 shows the results of reliability analysis between the two indicators, namely the implementation of education policy changes to the availability of professional teachers in $3 \mathrm{~T}$ areas. High reliability, empirical is shown by a number called reliability coefficient value. High reliability is indicated by the value of approaching the number 1 . The general agreement of reliability is considered quite satisfactory if $\geq 0.700$. Thus, both indicators have a level of reliability is quite satisfactory. Besides conducting reliability test, also inversion of correlation between indicators, as shown in table 2.

TABLE.2. MATRIXS INVERS OF POLICY IMPLEMENTATION CORRELATION

\begin{tabular}{|c|c|c|c|c|}
\hline Variable & $\mathbf{X}_{\mathbf{1}}$ & $\mathbf{X}_{\mathbf{2}}$ & $\mathbf{X}_{\mathbf{3}}$ & $\mathbf{X}_{\mathbf{4}}$ \\
\hline $\mathrm{X}_{1}$ & 1.488394668 & -0.28936 & -0.13943 & -0.174879879 \\
\hline $\mathrm{X}_{2}$ & -0.289359249 & 1.939761 & -0.62251 & -0.310620715 \\
\hline $\mathrm{X}_{3}$ & -0.139427334 & -0.62251 & 1.33308 & -0.123707187 \\
\hline $\mathrm{X} 4$ & -0.174879879 & -0.31062 & -0.12371 & 1.692872369 \\
\hline
\end{tabular}

Correlation coefficient is the measurement of covariant statistics or associations between two variables. The magnitude of the correlation coefficient ranges from $+1 \mathrm{~s} /$ $\mathrm{d}-1$. Correlation coefficient shows the strength (strength) of linear relationship and direction of relationship of two random variables. If positive correlation coefficient, then both variables have direct relationship. This means that if the value of variable $\mathrm{X}$ is high, then the value of variable $\mathrm{Y}$ will be high as well. Conversely, if the correlation coefficient is negative, then both variables have inverse relationships. This means that if the value of variable $\mathrm{X}$ is high, then the value of variable $\mathrm{Y}$ will be low (and vice versa). To facilitate the interpretation of the strength of the relationship between two variables the researcher gives the following criteria (Sarwono: 2006):

- 0: There is no correlation between two variables

- $>0$ - 0.25: The correlation is very weak

- $>0.25-0.5$ : Correlation is enough

- $>0.5-0.75$ : Strong correlation

- $>0.75-0.99$ : The correlation is very strong

- 1: Perfect correlation

TABLE 3. THE RESULT OF TEST ( $F_{\text {COUNT }}$ AND F $F_{\text {TABLE }}$ ) INFLUENCE OF EDUCATION POLICY IMPLEMENTATION TOWARD THE AVAILABILITY OF PROFESSIONAL TEACHERS IN 3T AREAS

\begin{tabular}{|c|c|c|}
\hline Variable & Fcount & F table \\
\hline Implementation of policy & 43.772 & 2,40 \\
\hline
\end{tabular}

Test $\mathrm{F}$ is done by comparing $\mathrm{F}$ count with Table $\mathrm{F}$, if $\mathrm{F}$ arithmetic $>$ from $\mathrm{F}$ table, (Ho at rejected $\mathrm{Ha}$ accepted) then 
model is significant. Thus, both indicators have significance of influence.

\section{CONCLUSION}

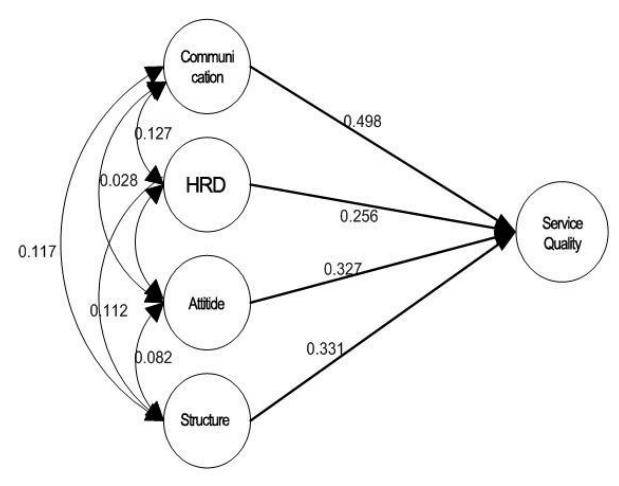

Fig. 1: Path Diagram Variable Of Policy Education Implementation Toward Professional Teacher's Availability

The influence of the factors changing the implementation of education policy towards the availability of professional teachers in the $3 \mathrm{~T}$ area has a significant improvement in the quality of the availability of professional teachers at vocational high schools in $3 \mathrm{~T}$ areas. The results showed that communication (X1) has a significant proximity in the implementation process of education policy, where the statistical test obtained a coefficient of 0.4980 lanes on the impact of total direct factor communication (X1) on the availability of professional teachers $(\mathrm{Y})=24.80 \%$ marked has gained support .

The results of research and statistical tests also support and relevant to the concept of implementation of education policy requires the existence of communication activities with indicators, namely: clarity scores level 872 (63.118) in the category of being, the accuracy of the scores provided by 65.868$)$ in the category of being, consistent scores level 303 (65.86) is located in the prologue is. This proves that the communication made in the implementation of changes in the implementation of educational policy, both between decision makers and apparatus of implementing agencies of a change in education policy, as a real effort has not been as expected to improve the quality of professional teachers in vocational schools in $3 \mathrm{~T}$ areas. Information in vocational high schools has problems in the implementation process of recruitment and placement of PPGT alumni, among others: the unclear status of teachers due to the absence of Master's Number Identity (NIG) on certificates of national written exam results received by PPGT alumni, lack of respect for district / city governments and provinces as local officials who should be responsible for their acceptance, changes in local policies due to changes in local leadership after the election of regional heads, and separate ministries of education with ministries of research and technology, resulting in no policy synchronization and low interministerial and regional coordination. The higher the responsiveness of local government to the existence of PPGT alumni to occupy the position of professional teachers in vocational high schools, the higher the availability of professional teachers in 3T areas.

The results of resource research (X2) show significant proximity in the implementation process of education policy changes. The results of the statistics obtained the coefficients 0,2563 lane with the influence of the availability of professional teachers in $3 \mathrm{~T}$ areas ( $\mathrm{Y}$ ) is $6,568 \%$. Marked received positive support. The results of research and test these statistics support and relevant to the concept of the implementation of education policy change toward the availability or professional teachers demanded the resources to the indicators, namely: staff scores level ( 66.84292 ) in the category of being, the ability of the scores 615 ( 66.84) in the category of being, the scores facilities 969 ( 70.21) is located in the category of good. This proved that resources conducted in the implementation of education policy change, both between the determination and decision makers and city officials and the implementor policy change, as a concrete not met in accordance with the hope of desired in improve the quality of professional teachers. Information from PPGT alumni is obtained for obstacles in the implementation process, among others: local government (both provincial and district / city governments in this case the Education Office does not fully facilitate PPGT alumni who have been educating the teaching profession to serve as professional teachers in vocational schools. This causes the PPGT alumni who are forced to become unemployed or apply for jobs other than to be teachers.

TABLE 4. THE RESULT OF VARIABEL TEST FROM EDUCATION POLICY IMPLEMENTATION CHANGE TOWARD THE AVAILABILITY OF PROFESIONAL TEACHERS IN 3T AREAS

\begin{tabular}{|c|c|c|c|}
\hline Dimension & Uji t count & $\begin{array}{c}\mathbf{t} \\
\text { table(5) }\end{array}$ & Explanation \\
\hline Communication $\left(\mathrm{X}_{1}\right)$ & 6.60851 & 1,99 & Significan \\
\hline $\begin{array}{c}\text { Human Resourse } \\
\left(\mathrm{X}_{2}\right)\end{array}$ & 2.97903 & 1,99 & Significan \\
\hline $\begin{array}{c}\text { Officer's attitude } \\
\left(\mathrm{X}_{3}\right)\end{array}$ & 4.58581 & 1,99 & Significan \\
\hline $\begin{array}{c}\text { Bureaucratic } \\
\text { Structure }\left(\mathrm{X}_{4}\right)\end{array}$ & 4.12625 & 1,99 & Signifikan \\
\hline
\end{tabular}

The result of attitude (X3) shows a close relationship in the process of implementing significant policy changes. The test results obtained by statistics of 0.3271 coefficient affect the availability of professional teachers (Y) as $10.696 \%$, they received positive support and relevant. The results of research and statistical tests is also supporting and relevant to the concept of the implementation of education policy change which demands implementing attitude with the indications namely: staff by 347 his score into the category of a good 726 personality his score into the category of a good and the readiness his score 1124 is at good category. This proves that the application of attitudes made in the implementation of changes in educational policy both between decision makers and implementers of education policy changes as concrete efforts are not met as is expected to increase the availability of professional teachers in vocational schools in 3T areas. Information on PPGT alumni found obstacles 
in the implementation process, among others: compliance level and lack of trust toward PPGT alumni, lack of formal legal recognition in the form of placement letter in secondary school, incentive that has not fulfilled regional minimum wage standard.

The results of research the bureaucratic structure $\left(\mathrm{X}_{4}\right)$ showed the closeness that significant in the process of implementation of policy change in education .The results of the statistics obtained the coefficients 0,3316 lane with the influence of total bureaucratic structure to the avalilability of professional teacgers in $3 \mathrm{~T}$ areas $(\mathrm{Y})$ is $10.997 \%$, marked has gained support and relevant to facilitate the implementation of professional teachers in vocational schools. The exercise of learning, obscurity structures, the bureaucrats the lack of synergy in work, the bureaucratic structures little regard for the interests of PPGT's alumni. Should be better as a bureaucratic structures in decision makers/chief executive /implementor, and officers the more effective implementation of policies in efforts to improve the quality of professional teachers in $3 \mathrm{~T}$ areas.

\section{ACKNOWLEDGMENT}

As a researcher of policy change of education and availability of professional teacher in $3 \mathrm{~T}$ areas, I would like to thank the manager of Profession Development Program Teacher (P3G) Universitas Negeri Makassar which has provided many data and information related to the implementation of Integrated Teacher Professional Education (PPGT). The same thing I say to PPGT alumni who have been willing to be respondents to fill out a questionnaire and become a research informan.

\section{REFERENCES}

[1] M. C. Chang, S. Shaeffer, S. Al-Sammarrai, A. B. Ragatz, J. de Ree, and R. Stevenson, "Teacher reform in Indonesia." Washington DC: World Bank. Available at: https://openknowledge. worldbank. org/bitstream/handle/10986/16355/9780821398, 2014.

[2] N. E. J. Abidin and N. A. Deliarnoor, "The Authority Of Borderland Management In Indonesia," Adv. Soc. Sci. Res. J., vol. 5, no. 4, 2018.

[3] E. Malihah and S. W. Tanshzil, "Scholars Remote Teaching Service: Indonesia's Geopolitical Strategy," in IOP Conference Series: Earth and Environmental Science, 2018, vol. 145, no. 1, p. 12008.

[4] A. Steinführer and A. Haase, "Demographic change as a future challenge for cities in East Central Europe," Geogr. Ann. Ser. B, Hum. Geogr., vol. 89, no. 2, pp. 183-195, 2007.

[5] A. V Diez-Roux, "Bringing context back into epidemiology: variables and fallacies in multilevel analysis.," Am. J. Public Health, vol. 88 , no. 2, pp. 216-222, 1998.

[6] A. F. Darrat, S. Rahman, and M. Zhong, "Intraday trading volume and return volatility of the DJIA stocks: A note," J. Bank. Financ., vol. 27, no. 10, pp. 2035-2043, 2003. 